10. Gupta R, Warren T, Wald A. Genital herpes. Lancet 2007;370:2127-37.

11. Maguire RA, Bergman N, Phillips DM. Comparison of microbicides for efficacy in protecting mice against vaginal challenge with herpes simplex virus type 2 cytotoxicity, antibacterial properties, and sperm immobilization. Sex Transm Dis 2001;28:259-65.

12. Mesquita PM, Wilson SS, Manlow P, et al. Candidate microbicide PPCM blocks human immunodeficiency virus type 1 infection in cell and tissue cultures and prevents genital herpes in a murine model. J Virol 2008;82:6576-84.

13. Tuyama AC, Cheshenko N, Carlucci MJ, et al. ACIDFORM inactivates herpes simplex virus and prevents genital herpes in a mouse model: optimal candidate for microbicide combinations. J Infect Dis 2006;194:795-803.

14. Rosenthal KS, Killius J, Hodnichak CM, et al. Mild acidic pH inhibition of the major pathway of herpes simplex virus entry into HEp-2 cells. J Gen Virol 1989:70:857-67.
15. Padian NS, van der Straten A, Ramjee G, et al. Diaphragm and lubricant gel for prevention of HIV acquisition in southern African women: a randomised controlled trial. Lancet 2007;370:251-61.

16. Hogrefe $\mathbf{W}$, Su X, Song J, et al. Detection of herpes simplex virus type 2-specific immunoglobulin $\mathrm{G}$ antibodies in African sera by using recombinant gG2, Western blotting, and gG2 inhibition. J Clin Microbiol 2002;40:3635-40.

17. van der Straten A, Shiboski S, Montgomery ET, et al. Patterns and predictors of adherence to diaphragm use in a phase III trial in sub-Saharan Africa: a trajectory analysis. J Acquir Immune Defic Syndr 2009:50:419-26.

18. Rupp R, Rosenthal SL, Stanberry LR. VivaGel (SPL7013 Gel): a candidate dendrimermicrobicide for the prevention of HIV and HSV infection. Int J Nanomedicine 2007;2:561-6.

19. Karim 0A, Karim SS, Frohlich JA, et al. Effectiveness and Safety of Tenofovir Gel, an Antiretroviral Microbicide, for the Prevention of HIV Infection in Women. Science 2010:329:1168-74.

LETTER

\section{Spontaneous remission of sexually transmitted diseases must be considered in randomised controlled trials}

Randomised controlled trials that test biomedical interventions to reduce sexually transmitted infections (STIs) have had very mixed results, ${ }^{1}{ }^{2}$ as have behavioural trials. ${ }^{34}$ It is only in the past 10 years that the field has recognised that chlamydia resolves itself without treatment in $50 \%$ of the cases, ${ }^{4}$ although the estimates range from $13 \%$ to $60 \% .^{5-7}$ The length of time to clear chlamydia infection varies from 60 days in women to up to 15 months in men. ${ }^{5}$ The speed of resolution is also subject to individual-level factors (eg, infection clears sooner in older people), making it difficult to determine sample sizes for randomised controlled trials with STI outcomes.

In a recent five-country trial, ${ }^{1}$ the determination of sample size to identify the necessary number of participants to demonstrate a reduction in bacterial STI was based primarily on chlamydia $(65.8 \%$ of the bacterial infections observed at recruitment; $10.3 \%$ prevalence) and trichomoniasis among women $(17.2 \%$ of infections; $4.89 \%$ prevalence). When we examined all the bacterial STIs 1 year later, the rates of chlamydia were more than $60 \%$ lower and the rates of trichomoniasis were $40 \%$ lower. Potentially, half of the new chlamydia and trichomoniasis infections may have spontaneously resolved, as suggested by the above studies, but the actual incidence rates may have been $25 \%$ more than those observed at 12 months (assuming a consistent rate of infection over time).

The emerging data on spontaneous remission rates raises serious questions on how to design effective evaluations to demonstrate reductions in STIs. Randomised controlled trials must be designed to have shorter periods between assessments. It is also likely that there is a variance in the rates of clearance, although it is unclear in what direction and for whom the variations will apply. Thus, the design of future multisite trials must cautiously estimate STI infections, given the emerging data on spontaneous remissions or clearing of infections, and consider much shorter follow-up periods, even for long-term longitudinal trials.

Mary Jane Rotheram-Borus, ${ }^{1}$ Zunyou $\mathrm{Wu}^{2}{ }^{2} \mathrm{Li} \mathrm{Li}^{1}{ }^{1}$ Roger Detels, ${ }^{1}$ Li-Jung Liang, ${ }^{1}$ and the NIMH Collaborative HIV/STD Prevention Trial Group

${ }^{1}$ University of California at Los Angeles, Semel Institute for Neuroscience and Human Behavior, Center for Community Health, Los Angeles, California, USA;

${ }^{2}$ National Center for AIDS/STD Control and Prevention, Chinese Centers for Disease Control and Prevention, Beijing, China

Correspondence to Dr Mary Jane Rotheram-Borus, University of California, Semel Institute for Neuroscience and Human Behavior, 10920 Wilshire Boulevard, Suite 350, Los Angeles, CA 90024, USA;

cchpublications@mednet.ucla.edu

Funding NIMH provided funding for this multisite study.

Competing interests None.

Patient consent All human subjects signed the informed consent forms that were reviewed and approved by the Institutional Review Boards at UCLA and the China CDC

Ethics approval UCLA SG-IRB; RTI IRB; Chinese Centers for Disease Control IRB.
Provenance and peer review Not commissioned; internally peer reviewed.

Accepted 16 February 2011

Published Online First 1 April 2011

Sex Transm Infect 2011;87:305

doi:10.1136/sextrans-2011-050009

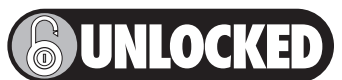

This paper is freely available online under the BMJ Journals unlocked scheme, see http://sti.bmj.com/site/ about/unlocked xhtml

\section{REFERENCES}

1. NIMH Collaborative HIV/STD Prevention Trial Group. Results of the NIMH Collaborative HIV/STD prevention trial of a community popular opinion leader intervention. J Acquir Immune Defic Syndr 2010;54:204-14.

2. The Explore Study Group. Effects of a behavioural intervention to reduce acquisition of HIV infection among men who have sex with men: the EXPLORE randomised controlled study. Lancet 2004;364:41-50.

3. Wawer MJ, Sewankambo NK, Serwadda D, et al. Control of sexually transmitted diseases for AIDS prevention in Uganda: a randomized community trial. Rakai Project Study Group. Lancet 1999;353:525-35.

4. Gisselquist D, Potterat JJ. Confound it: latent lessons from the Mwanza trial of STD treatment to reduce HIV transmission. Int J STD AIDS 2003:14:179-84.

5. Golden MR, Schillinger JA, Markowitz $L$, et al Duration of untreated genital infections with Chlamydia trachomatis: a review of the literature. Sex Transm Dis 2000;27:329-37.

6. Brunham RC, Rey-Ladino J. Immunology of chlamydia infection: implication for a Chlamydia trachomatis vaccine. Nat Rev Immunol 2005;5:149-61.

7. Parks KS, Dixon PB, Richey CM, et al. Spontaneous clearance of Chlamydia trachomatis infection in untreated patients. Sex Transm Dis 1997;24:229-35. 